\title{
HUBUNGAN ANTARA KARAKTERISTIK DENGAN KADAR FERRITIN PADA IBU HAMIL TRIMESTER III DI PUSKESMAS JAGIR SURABAYA
}

\author{
Nur Masruroh, Gilang Nugraha \\ (Universitas Nahdlatul Ulama Surabaya )
}

\begin{abstract}
Ferritin is an iron storage protein and is extracellular in serum. Ferritin serum functions as a clinical marker of the body's iron stores status. Low ferritin levels illustrate the low iron stores that lead to iron deficiency conditions resulting in anemia in pregnant women. Some maternal characteristics affect ferritin levels in pregnant women.This study aims to determine the relationship between characteristics with ferritin levels. Taking the location of the research at the Jagir Public Health Center in Surabaya with a sample of 30 respondents who met the inclusion and exclusion criteria. The research method was observational analytic by taking maternal venous blood to be examined for ferritin levels then looking for the relationship with the characteristics of pregnant women and analyzed using chi square. More than half (83\%) of respondents had ferritin levels $<30 \mu \mathrm{g} / \mathrm{ml}$. The results of the analysis using chi square $(p=<0.05)$ show that there is a relationship between age (0.04) and parity (0.01) with ferritin levels. No relationship between education (0.71) and employment (0.23) with ferritin levels. Age and parity were related to ferritin levels. Education and work are not related to ferritin levels for pregnant women in the third trimester. It is expected that pregnant women increase consumption of foods that contain lots of iron to prevent anemia and health workers provide socialization of foods that contain lots of iron.
\end{abstract}

Keywords: characteristics; pregnant women; ferritin levels

\begin{abstract}
Abstrak
Ferritin adalah protein penyimpanan zat besi dan terdapat secara ekstraseluler dalam serum. Serum ferritin berfngsi sebagai penanda klinis status simpanan zat besi tubuh. Kadar ferritin yang rendah menggambarkan rendahnya simapanan besi yang mengarah pada kondisi defisiensi besi yang berakibat terjadinya anemia pada ibu hamil. Beberapa karakteristik ibu mempengaruhi kadar ferritin pada ibu hamil. Penelitian ini bertujuan untuk mengetahui hubungan karakteristik dengan kadar ferritin pada ibu hamil trimester III. Mengambil lokasi penelitian di Puskesmas Jagir Surabaya dengan jumlah sampel sebanyak 30 responden yang telah memenuhi kriteria inklusi dan eksklusi. Metode penelitiannya adalah analitik observasional dengan mengambil darah vena ibu untuk diperiksa kadar ferritin kemudian dicari hubungannya dengan karakteristik ibu hamil serta dianalisis menggunakan chi square. Lebih dari setengah (83\%) responden memiliki kadar ferritin $\leq 30$ $\mu \mathrm{g} / \mathrm{ml}$. Hasil analisis menggunakan chi square ( $p$ value $=<0,05)$ menunjukkan bahwa terdapat hubungan antara usia $(0,04)$ dan paritas $(0,01)$ dengan kadar ferritin ibu hamil trimester III. Serta tidak terdapat hubungan antara pendidikan $(0,71)$ dan pekerjaan $(0,23)$ dengan kadar ferritin pada ibu hamil trimester III. Usia dan paritas berhubungan dengan kadar ferritin pada ibu hamil trimester III. Sedangkan pendidikan dan pekerjaan tidak berhubungan dengan kadar ferritin ibu hamil trimester III. Diharapkan ibu hamil meningkatkan konsumsi makanan yang banyak mengandung zat besi untuk mencegah anemia dan petugas kesehatan memberikan sosialisasi jenis makanan yang banyak mengandung zat besi.
\end{abstract}

Kata kunci : karakteristik; ibu hamil; kadar ferritin 


\section{PENDAHULUAN}

Anemia defisiensi besi merupakan masalah gizi yang banyak terjadi pada ibu hamil yang merupakan masalah gizi mikro terbesar dan tersulit diatasi di seluruh dunia. Laporan World Health Organization (WHO) menunjukkan bahwa terdapat $52 \%$ ibu hamil mengalami anemia di negara berkembang. Di Indonesia dilaporkan bahwa dari sekitar 4 juta ibu hamil, separuhnya mengalami anemia gizi dan satu juta lainnya mengalami kekurangan energi kronis ${ }^{1}$. Ibu hamil membutuhkan $1000 \mathrm{mg}$ besi perhari untuk pertambahan volume darah maternal dan masa sel-sel darah merah fetal. Meskipun tingkat penyerapannya cukup tinggi tetapi seringkali anemia tetap terjadi, umumnya yang terjadi adalah anemia defisiensi besi. Sehingga transfer zat besi akan mengalami gangguan akibat defisiensi tersebut. Transfer zat besi tersebut dimulai dan diatur oleh plasenta. ${ }^{2}$

Pemeriksaan ferritin serum terbukti sebagai indikator paling dini menurun apabila terjadi penipisan simpanan zat besi dan memiliki prosedur yang lebih tidak invasif. Ferritin adalah protein penyimpanan zat besi dan terdapat secara ekstraseluler dalam serum. Ferritin berfungsi sebagai penanda klinis status simpanan zat besi tubuh ${ }^{3}$. Pemeriksaan feritin serum (serum feritin, SF) adalah parameter pemeriksaan yang digunakan untuk menilai simpanan zat besi dalam tubuh. Pemeriksaan SF memiliki keterbatasan, kadarnya dipengaruhi oleh adanya peradangan karena feritin merupakan protein fase akut ${ }^{4}$

Perempuan hamil membutuhkan $1000 \mathrm{mg}$ besi perhari untuk pertambahan volume darah maternal dan masa sel-sel darah merah fetal. Meskipun tingkat penyerapannya cukup tinggi namun anemia tetap terjadi, umumnya anemia defisiensi besi. Transfer zat besi akan mengalami gangguan akibat defisiensi tersebut. Transfer tersebut diatur oleh plasenta. Feritin merupakan protein yang penting dalam metabolisme besi. Pada kondisi normal, ferritin menyimpan besi yang dapat diambil kembali untuk digunakan sebagai kebutuhan. Pada keadaan kelebihan besi, simpanan besi tubuh sangat meningkat dan jauh lebih banyak ferritin yang terdapat di jaringan, misalnya hati dan limpa ${ }^{2}$.

Besi bebas terdapat dalam dua bentuk yaitu ferro (Fe2+) dan ferri $(\mathrm{Fe} 3+)$. Konversi kedua bentuk tersebut relatif mudah. Pada konsentrasi oksigen tinggi, umumnya besi dalam bentuk ferri karena terikat hemoglobin sedangkan pada proses transport transmembran, deposisi dalam bentuk feritin dan sintesis heme, besi dalam bentuk ferro ${ }^{5}$. Dalam tubuh, besi diperlukan untuk pembentukan kompleks besi sulfur dan heme. Kompleks besi sulfur diperlukan dalam kompleks enzim yang berperan dalam metabolisme energi. Heme tersusun atas cincin porfirin dengan atom besi di sentral cincin yang berperan mengangkut oksigen pada hemoglobin dalam eritrosit dan mioglobin dalam otot ${ }^{6}$

Kadar serum feritin adalah parameter yang paling berguna, mudah, dan dipertimbangkan sebagai penanda (marker) indirek terbaik dari cadangan besi yang tersedia untuk menilai defisiensi besi. Kadar di bawah $15 \mu \mathrm{g} / \mathrm{L}$ dapat menegakkan diagnostik 
defisiensi besi. Feritin merupakan protein fase akut yang juga mungkin meningkat selama infeksi Hal ini menyebabkan nilai plasma feritin menjadi normal atau meningkat palsu sehingga perlu kehati-hatian dalam interpretasi untuk penegakan defisiensi besi. ${ }^{7}$ Wanita hamil sangat rentan terjadi anemia defisiensi besi karena pada kehamilan kebutuhan oksigen lebih tinggi sehingga memicu peningkatan produksi eritropoietin. Akibatnya, volume plasma bertambah dan sel darah merah (eritrosit) meningkat. Namun peningkatan volume plasma terjadi dalam proporsi yang lebih besar jika dibandingkan dengan peningkatan eritrosit sehingga penurunan konsentrasi hemoglobin $(\mathrm{Hb})$ akibat hemodilusi. ${ }^{8}$

Anemia sangat berpengaruh dalam kehamilan karena dapat berakibat fatal jika tidak segera diatasi diantaranya adalah dapat menyebabkan abortus, partus prematurus, inersia uteri, partus lama, atonia uteri dan menyebabkan perdarahan serta shock. Sedangkan pengaruh anemia terhadap hasil konsepsi diantaranya dapat menyebabkan kematian janin dalam kandungan, kematian janin saat lahir, meningkatnya kematian perinatal, prematuritas serta cacat bawaan. ${ }^{9}$ Studi pendahuluan menunjukkan bahwa pada tahun 2018 di Puskesmas Jagir Surabaya dari semua ibu hamil yang berkunjung $38 \%$ mengalami anemia. Penelitian ini bertujuan untuk melihat hubungan antara karakteristik dan kadar serum ferritin pada ibu hamil trimester III di Puskesmas Jagir Surabaya.

\section{METODE PENELITIAN}

Jenis penelitian ini ialah deskriptif prospektif dengan desain potong lintang. Penelitian ini dilakukan di Puskesmas Jagir Surabaya pada bulan Maret-Mei 2019. Pemilihan sampel menggunakan metode simple random sampling dengan kriteria inklusinya adalah ibu hamil trimester III, sehat dan bersedia menjadi resonden dengan menandatangani inform consent yang berkunjung di Puskesmas Jagir Surabaya pada periode penelitian sejumlah 30 orang. Karakteristik ibu hamil (usia, paritas, pendidikan, pekerjaan) diambil dari data sekunder dengan menggunakan data dari buku kesehatan ibu dan anak (buku KIA). Sedangkan data primer untuk kadar ferritin diambil melalui pengambilan darah vena sebanyak $3 \mathrm{cc}$. Pengambilan darah vena dilakukan untuk pengukuran serum ferritin yang dilakukan di Laboratorium Klinik Paramita Surabaya. Data dianalisis menggunakan Chi Square.

\section{HASIL PENELITIAN}

A. Karakteristik Responden

Tabel 1 Distribusi Responden Berdasarkan Karakteristik Usia, Paritas, Pendidikan dan Pekerjaan di Puskesmas Jagir Surabaya

\begin{tabular}{cccc}
\hline Variabel & Kategori & f & Persentase (\%) \\
\hline Usia & $<20$ tahun & 2 & 6,6 \\
& $21-34$ tahun & 24 & 80 \\
& $>35$ tahun & 4 & 13,4 \\
\hline Paritas & Primigravida & 10 & 33,3 \\
& Multigravida & 20 & 66,7 \\
\hline
\end{tabular}




\begin{tabular}{cccc}
\hline Pendidikan & SMP & 2 & 6,6 \\
& SMA & 19 & 63,3 \\
& PT & 9 & 30,1 \\
\hline Pekerjaan & Bekerja & 11 & 36,7 \\
& Tidak bekerja & 19 & 63,3 \\
\hline
\end{tabular}

Sumber : data primer bulan Maret-Mei 2019

Dari tabel diatas diketahui bahwa sebagian besar responden (80\%) berada di rentang umur 21-34 tahun dan sebagian kecil (6,6\%) responden yang berumur $\leq 20$ tahun. Lebih dari setengah $(66,7 \%)$ responden berparitas multigravida dan kurang dari setengah $(33,3 \%)$ yang berparitas primigravida. Dapat dilihat juga bahwa lebih dari setengah $(63,3 \%)$ responden memiliki pendidikan terakhir di SMA dan hanya sebagian kecil (6,6\%) responden yang berpendidikan terakhir di SMP sedangkan sisanya hampir setengahnya $(30,1 \%)$ berpendidikan terakhir di Perguruan Tinggi. Lebih dari setengah responden (63,3\%) bekerja dan hampir setengah $(36,7 \%)$ responden yang tidak bekerja.

B. Kadar Serum Ferritin

Tabel 2 Kadar Serum Ferritin ibu hamil trimester III di Puskesmas Jagir Surabaya

\begin{tabular}{ccc}
\hline Serum ferritin & $\mathbf{f}$ & Persentase \\
\hline$\leq 30 \mathrm{ng} / \mathrm{ml}$ & 25 & 83,3 \\
\hline $30 \mathrm{ng} / \mathrm{ml}$ & 5 & 16,7 \\
\hline Total & 30 & 100
\end{tabular}

Sumber : data primer bulan Maret-Mei 2019

Dari tabel diatas diketahui bahwa sebagian besar (83,3\%) responden memiliki kadar serum ferritin $\leq 30 \mathrm{ng} / \mathrm{ml}$ dan sebagian kecil responden $(16,7 \%)$ memiliki kadar serum ferritin $>30 \mu \mathrm{g} / \mathrm{ml}$.

C. Hubungan Antara Karakteristik Responden dan kadar Ferritin Ibu Hamil Trimester III di Puskesmas Jagir Surabaya

Tabel 3 Hubungan Antara Karakteristik Responden dan Kadar Ferritin Ibu Hamil Trimester III di Puskesmas Jagir Surabaya

\begin{tabular}{|c|c|c|c|c|c|c|c|}
\hline \multirow[t]{3}{*}{ Variabel } & \multicolumn{4}{|c|}{ Kadar Ferritin Serum } & \multicolumn{2}{|c|}{ Total } & \multirow{3}{*}{$\begin{array}{l}\text { p value } \\
<0,005\end{array}$} \\
\hline & \multicolumn{2}{|c|}{$\leq 30 \mu \mathrm{g} / \mathrm{ml}$} & \multicolumn{2}{|c|}{$>30 \mu \mathrm{g} / \mathrm{ml}$} & \multirow{2}{*}{$f$} & \multirow{2}{*}{$\%$} & \\
\hline & $\bar{f}$ & $\%$ & $\mathbf{n}$ & $\%$ & & & \\
\hline Usia & & & & & & & 0,004 \\
\hline$<20$ tahun & 2 & 8 & 0 & 0 & 2 & 6 & \\
\hline$\overline{2} 1-34$ tahun & 20 & 80 & 4 & 80 & 24 & 80 & \\
\hline$\geq 35$ tahun & 3 & 12 & 1 & 20 & 4 & 14 & \\
\hline Paritas & & & & & & & 0,001 \\
\hline Primiaravida & 7 & 28 & 3 & 60 & 10 & 33 & \\
\hline Multigravida & 18 & 71 & 2 & 40 & 20 & 67 & \\
\hline Pendidikan & & & & & & & 0,71 \\
\hline SMP & 2 & 8 & 0 & 0 & 2 & 6 & \\
\hline SMA & 15 & 60 & 4 & 80 & 19 & 63 & \\
\hline Perguruan Tinggi & 8 & 32 & 1 & 20 & 9 & 31 & \\
\hline
\end{tabular}




\begin{tabular}{lccccccc}
\hline Pekerjaan & & & & & & 0,23 \\
Bekerja & 9 & 36 & 2 & 40 & 11 & 63 & \\
Tidak bekerja & 16 & 64 & 3 & 60 & 19 & 37 & \\
\hline
\end{tabular}

Sumber : data primer bulan Maret-Mei 2019

a. Hubungan Antara Usia Dengan Kadar Ferritin Ibu Hamil Trimester III di Puskesmas Jagir Surabaya

Sebagian besar (80\%) responden yang berusia 21-34 tahun memiliki kadar serum ferritin $\leq 30 \mu \mathrm{g} / \mathrm{ml}$ dan sebagian responden (80\%) responden yang berusia 21-34 tahun memiliki kadar serum ferritin sebesar $>30 \mu \mathrm{g} / \mathrm{ml}$. Hasil analisis bivariat menggunakan chi square didapatkan hasil $0,004(<0,005)$ artinya usia berhubungan dengan kadar ferritin pada ibu hamil trimester III di Puskesmas Jagir Surabaya.

b. Hubungan antara Paritas Dengan Kadar Ferritin Ibu Hamil Trimester III di Puskesmas Jagir Surabaya

Sebagian besar $(71 \%)$ responden yang hamil anak kedua atau lebih memiliki kadar ferritin $\leq 30 \mu \mathrm{g} / \mathrm{ml}$ dan sebagian kecil (28\%) responden yang hamil anak pertama memiliki kadar ferritin $\leq 30 \mu \mathrm{g} / \mathrm{ml}$. Hasil analisis bivariat dengan chi square mendapatkan hasil 0,001 $(<0,005)$ artinya terdapat hubungan antara paritas dan kadar ferritin pada ibu hamil trimester III di Puskesmas Jagir Surabaya.

c. Hubungan antara Pendidikan dengan Kadar Ferritin Ibu Hamil Trimester III di Puskesmas Jagir Surabaya.

Lebih dari setengah (60\%) responden berpendidikan terakhir di SMA memiliki kadar ferritin $\leq 30 \mu \mathrm{g} / \mathrm{ml}$. Kurang dari setengah (32\%) responden berpendidikan terakhir di Perguruan Tinggi memiliki kadar ferritin $\leq 30 \mu \mathrm{g} / \mathrm{ml}$ dan sebagian kecil (8\%) responden berpendidikan terakhir di SMP memiliki kadar ferritin $\leq 30 \mu \mathrm{g} / \mathrm{ml}$. Hasil analisis bivariat menggunakan chi square didapatkan hasil $0,71(<0,05)$ yang berarti tidak ada hubungan antara pendidikan dan kadar ferritin pada ibu hamil trimester III di Puskesmas Jagir Surabaya.

d. Hubungan antara Pekerjaan dengan Kadar Ferritin Ibu Hamil Trimester III di Puskesmas Jagir Surabaya

Lebih dari setengah (64\%) responden yang bekerja memiliki kadar ferritin $\leq 30$ $\mu \mathrm{g} / \mathrm{ml}$. Sedangkan kurang dari setengah (34\%) responden yang tidak bekerja memiliki kadar ferritin $\leq 30 \mu \mathrm{g} / \mathrm{ml}$. Hasil analisis bivariat menggunakan chi square didapatkan hasil $0,23(<0,05)$ yang artinya tidak ada hubungan antara pekerjaan dan kadar ferritin pada ibu hamil trimester III di Puskesmas Jagir Surabaya. 


\section{PEMBAHASAN}

a. Hubungan Antara Usia Dengan Kadar Ferritin Ibu Hamil Trimester III di Puskesmas Jagir Surabaya

Penelitian yang dilakukan oleh Judistiani di tahun 2018 menunjukkan bahwa ibu hamil yang memiliki kadar serum ferritin rendah ada pada rentang usia tidak berisiko di usia 20-35 tahun. Kebanyakan wanita dengan rentang usia 20-30 tahun diketahui belum dapat mengimbangi kehilangan zat besi akibat menstruasi dengan memiliki asupan zat besi yang masih rendah ${ }^{3}$ Usia ibu hamil yang berkisar antara 16-18 tahun rentan mengalami anemia karena usia risiko tinggi untuk hamil. Wanita hamil usia usia $<20$ tahun dan 20-35 tahun memiliki tingkat prevalensi kadar ferritin serum rendah lebih tinggi dibandingkan dengan kelompok wanita hamil usia > 35 tahun. ${ }^{10}$ Selama kehamilan, kadar feritin berubah sesuai penambahan gestasi dan mencapai kadar maksimum pada usia gestasi 12-16 minggu lalu menurun hingga mencapai kadar minimum pada trimester III. Kadar feritin ibu yang tinggi dapat dihubungkan dengan outcome bayi yang kurang baik. Peningkatan konsentrasi serum feritin selama trimester ketiga mungkin menjadi bagian dari respon fase akut, yang menunjukkan peningkatan risiko kehamilan ${ }^{11}$

Kebutuhan besi tubuh meningkat pada masa pertumbuhan serta masa kehamilan. Besi dibutuhkan selama kehamilan untuk bayi, plasenta dan peningkatan jumlah sel darah merah. Total kebutuhan besi selama kehamilan sekitar $1000 \mathrm{mg}$. Jika cadangan besi kosong maka total kebutuhan besi selama kehamilan harus dipenuhi dari diet dan suplementasi. Pada kehamilan trimester pertama tidak memerlukan tambahan besi untuk wanita hamil, fetus maupun plasenta. Kebutuhan besi pada saat ini biasanya lebih rendah dibandingkan dengan wanita yang tidak hamil oleh karena rendahnya aktivitas eritropoetik. Pada kehamilan trimester ke dua, kebutuhan besi lebih tinggi dan akan terus meningkat sampai akhir kehamilan ${ }^{12}$

b. Hubungan antara Paritas Dengan Kadar Ferritin Ibu Hamil Trimester III di Puskesmas Jagir Surabaya

Penelitian yang dilakukan di kota Malang tahun 2017 menunjukkan hasil bahwa pengetahuan, pendidikan dan pekerjaan tidak berhubungan dengan kadar ferritin pada ibu hamil. ${ }^{13}$ Ibu hamil dengan jumlah paritas $\geq 2$ memiliki prevalensi kadar ferritin serum rendah yang lebih tinggi dibandingkan dengan subjek dengan jumlah paritas < 2.24. Judistiani juga menjelaskan bahwa jumlah paritas akan berkaitan dengan pendeknya interval antar kelahiran yang memungkinkan untuk menguras cadangan zat besi dan apabila asupan zat besi tidak dapat mengimbangi kebutuhan ibu dapat mengalami defisiensi besi ${ }^{3}$ 
Hal tersebut tidak sejalan dengan penelitian yang dilakukan oleh Rahma dan Lubis di tahun 2019 yang menyatakan bahwa tidak ada hubungan antara paritas dan kadar ferritin pada ibu hamil. Kadar feritin yang rendah menggambarkan rendahnya simpanan besi yang mengarah pada kondisi defisiensi besi yang berakibat terjadinya anemia pada ibu hamil, tetapi banyaknya jumlah kehamilan tidak berhubungan dengan kadar ferritin ${ }^{14}$

c. Hubungan antara Pendidikan dengan Kadar Ferritin Ibu Hamil Trimester III di Puskesmas Jagir Surabaya.

Tingkat pendidikan tidak dapat dibandingkan dengan kadar ferritin serum yang rendah. Pada penelitian Judistiani, dkk. menunjukkan pada kadar ferritin serum rendah subjek dengan tingkat pendidikan yang rendah memiliki memiliki jumlah yang secara signifikan tidak tinggi ${ }^{3}$

d. Hubungan antara Pekerjaan dengan Kadar Ferritin Ibu Hamil Trimester III di Puskesmas Jagir Surabaya

Penelitian yang dilakukan di kota Malang tahun 2017 menunjukkan hasil bahwa pengetahuan, pendidikan dan pekerjaan tidak berhubungan dengan kadar ferritin pada ibu hamil. ${ }^{13}$ Jenis pekerjaan tidak dapat dibandingkan dengan kadar serum ferritin yang rendah pada ibu hamil karena pada penelitian tersebut kadar ferritin rendah pada responden yang bekerja memiliki jumlah yang secara signifikan tidak tinggi. ${ }^{3}$ Nilai kadar serum ferritin yang melebihi batas atas maksimal dapat menandakan adanya kondisi iron overload. Sebaliknya, kadar serum ferritin yang lebih rendah dari $10 \mathrm{ng} / \mathrm{mL}$ dapat menandakan penurunan simpanan zat besi dalam tubuh. ${ }^{15}$ Ferritin adalah protein penyimpanan zat besi dan terdapat secara ekstraseluler dalam serum. Ferritin berfungsi sebagai penanda klinis status simpanan zat besi tubuh. Mobilisasi cadangan besi tubuh dapat diperkirakan dengan konsentrasi serum ferritin, dimana pada orang yang sehat merupakan biomarker yang baik bagi status besi ${ }^{2}$

\section{SIMPULAN DAN SARAN}

Usia dan paritas berhubungan dengan kadar ferritin pada ibu hamil trimester III di Puskesmas Jagir Surabaya. Sedangkan pendidikan dan pekerjaan tidak berhubungan dengan kadar ferritin ibu hamil trimester III di Puskesmas Jagir Surabaya. Diharapkan ibu hamil meningkatkan konsumsi makanan yang banyak mengandung zat besi untuk mencegah anemia dan petugas kesehatan memberikan sosialisasi jenis makanan yang banyak mengandung zat besi.

\section{DAFTAR PUSTAKA}

1. Kemenkes RI. Pedomman Gizi Seimbang. Jakarta: Kemenkes RI Dirjen Bina Gizi; 2014. 
2. Pontoh S, Mayulu N, Engka JN. Hubungan Kadar Ferritin Dan Asupan Protein Pada Ibu Hamil Trimester li-lii Di Kabupaten Bolaang Mongondow Utara. Jurnal e-Biomedik. 2015;3(3).

3. Raden Tina Dewi Judistiani, Mochamad Ari Wibowo, Adhi K Sugianli DP. Kecukupan Asupan Zat Besi Dan Protein Pada Ibu Hamil Trimester 1: Masihkah Berkaitan Dengan Kadar Ferritin Serum ? 2018;

4. Nugraha G, Masruroh N. Pengaruh Peningkatan Laju Endap Darah Terhadap Hasil Pemeriksaan Feritin Serum Pada Ibu Hamil. Medical Technology and Public Health Journal. 2019;3(2):127-32.

5. Wildayani D, Yusrawati, Ali H. Pengaruh Pemberian Tablet Zink dan Besi terhadap Kadar Hemoglobin dan Feritin pada Ibu Hamil Anemia Defisiensi Besi. Jurnal Kesehatan Andalas [Internet]. 2018;7(Supplement 4):1-5. Available from: http://jurnal.fk.unand.ac.id/index.php/jka/article/view/913

6. Susiloningtyas I. Pemberian Zat Besi (Fe) Dalam Kehamilan. Majalah IImiah Sultan Agung. 2012;50:128.

7. Bambang Sasangka, Ratnaningsih $\mathrm{T}$. Reticulocyte hemoglobin content $(\mathrm{CHr})$ untuk skrining defisiensi besi pada ibu hamil. Jrnal Gizi Klinik Indonesia. 2019;6(1):40-7.

8. Herawati C, Astuti S. Faktor-Faktor yang Berhubungan dengan Anemia Gizi pada Ibu Hamil di Puskesmas Jalaksana Kuningan Tahun 2010. Jurnal Kesehatan Kartika [Internet]. 2010;51-8. Available from: http://www.stikesayani.ac.id/publikasi/ejournal/filesx/2010/201012/201012-007.pdf

9. Ari Madi Yanti D, Sulistianingsih A, Keisnawati. Faktor-Faktor Terjadinya Anemia pada Ibu Primigravida di Wilayah Kerja Puskesmas Pringsewu Lampung. Jurnal Keperawatan [Internet]. 2015;6(2):79-87. Available from: http://download. portalgaruda.org/article. php?article=424747\&val=278\&title=FAKTORFAKTOR TERJADINYA ANEMIA PADA IBU PRIMIGRAVIDA DI WILAYAH KERJA PUSKESMAS PRINGSEWU LAMPUNG

10. Lisfi I, Serudji J, Kadri H. Hubungan Asupan Fe dan Vitamin A dengan Kejadian Anemia pada Ibu Hamil Trimester III di Puskesmas Air Dingin Kota Padang. Jurnal FK UNAND [Internet]. 2017;6(1):191-5. Available from: jurnal.fk.unand.ac.id/index.php/jka/article/download/669/534

11. Ulfah M, Masrul M, Amir A. Peranan Kadar Feritin Serum terhadap Kejadian Preeklampsia. Jurnal Kesehatan Andalas. 2015;4(3):781-5.

12. Ani LS, Bakta M, Kedokteran F. Kadar Feritin Serum Dan Hemoglobin Pada Wanita Pasangan. Jurnal Gizi dan Pangan. 2010;5(1):26-30.

13. Partinah R. Gambaran Kadar Ferritin Serum Wanita Hamil Trimester I Di Rumah Sakit Umum Hasanah Graha Afiah Depok. UIN Syarif Hidayatullah. 2017;(April 2016):1-52. 
14. Rahma H, Lubis Z. ARTIKEL PENELITIAN Korelasi Kadar Hepcidin Dan Kadar Feritin. 2019;12(1):1-6.

15. Putri NMG, Probosari E. Perbedaan Kadar Serum Ferritin Remaja Putri Status Gizi Normal Dan Status Gizi Lebih. Perbedaan Kadar Serum Ferritin Remaja Putri Status Gizi Normal Dan Status Gizi Lebih. 2016;5(4):393-401. 